\title{
ANALISIS TITIK IMPAS USAHA TERNAK AYAM RAS PETELUR "DHARMA GUNAWAN"DI KELURAHAN PANIKI BAWAH KECAMATAN MAPANGET KOTA MANADO (STUDI KASUS)
}

\author{
Andrecesar A. Rembet; F. S. Oley *); A. Makalew *); E. K. M. Endoh *) \\ Fakultas Peternakan Universitas Sam Ratulangi Manado, 95115. \\ email: andrerembet@yahoo.co.id
}

\begin{abstract}
ABSTRAK
Penelitian dilaksanakan di Kota Manado, pada perusahaan peternakan Ayam Ras Petelur Dharma Gunawan yang berlokasi di Kelurahan Paniki Bawah Kecamatan Mapanget.Masalah dalam penelitian ini adalah berapa besar tercapainya titik impas dan berapa besar keuntungan usaha ternak ayam ras petelur Dharma Gunawan. Tujuan penelitian adalah untuk mengetahui titik impas dan keuntungan usaha ternak ayam ras petelur Dharma Gunawan. Metode penelitian yang digunakan adalah metode studi kasus. Data diperoleh melalui wawancara secara langsung kepada peternak dengan menggunakan kuesioner. Model analisis yang digunakan yaitu model analisis deskriptif dengan cara verbal dan matematis. Cara verbal adalah cara yang menggunakan kata-kata untuk menerangkan sesuatu hal, sedangkan cara matematis dengan menggunakan analisis titik impas.Penelitian dilakukan pada satu periode produksi, menunjukkan bahwa dalam pengalokasian biaya menyangkut biaya tetap total sebesar $\mathrm{Rp}$ 413.793.300,-, dan biaya variabel total sebesar Rp 6.298.040.700,- sedangkan penerimaan total sebesar $\mathrm{Rp}$ 9.019.195.160, sehingga keuntungan
\end{abstract}

*Dosen Pembimbing usaha ternak ayam ras petelur sebesar Rp 2.307.361.460,-. Kesimpulan penelitian ini yaitu titik impas tercapai pada unit 1.877.804,51 dan penerimaan sebesar Rp 1.799.100.000,- dari hasil penjualan telur rata-rata. Usaha ternak ayam petelur Dharma Gunawan prospektif dan menguntungkan.

Kata Kunci:Analisis, Titik Impas, Usaha Ternak Ayam Ras Petelur

\section{ABSTRACT}

BREAK EVEN
ANALYSISLIVESTOCK
BUSINESS LAYING CHICKEN
"DHARMA GUNAWAN" IN
PANIKI BAWAH VILLAGE
MAPANGET
MANADO CITY
(CASE STUDY). The study was
conducted in the Dharma Gunawan layer chicken farm. The farm is a poultry farm business in the city of Manado, located in Paniki Bawah, Mapanget District. The problem in this study is howbreakeven and profit achievement of Dharma Gunawan layer chicken farm. The research objective was to determine the breakeven point and profit of Dharma Gunawan layer chicken farm. The research method used is case study method. Dataobtained through direct interviews with farmer using a questionnaire. The analysis model used in the study is a descriptive 
analysis of verbal and mathematical way models. Verbal is the way how to use words to explain something, while mathematical way is the way of breakeven analysis. The study on allocation of costs and profitwas calculated in a production period on the chicken layer farm, showed that involves fixed costs total is Rp 413 $793300,-$, total variable costs is $\mathrm{Rp}$ $6,298,040,700$,- and total revenue is Rp 9,019,195,160,-, so profitof Dharma Gunawan chicken layer farm is $\mathrm{Rp}$ 2.307.361.460,-. The conclusion are reached breakeven in units is $1,877,804.51$ and in revenue is $\mathrm{Rp}$ 1.7991 billion,- from the average sale of eggs. The Dharma Gunawan layer chicken farm is prospective and profitable.

Keywords: Analysis, Break Even Point, Layer Chicken Farm

\section{PENDAHULUAN}

Pembangunan sektor pertanian memegang peranan yang sangat penting, selain tanaman pangan, hortikultura (buah-buahan), perkebunan, pembangunan pertanian juga mencakup sub sektor peternakan dan perikananuntuk mencukupi kebutuhan pangan masyarakat dunia.Salah satu jenis ternak penghasil daging dan telur adalah ternak ayam, namun tidak semua spesies ayam adalah penghasil daging dan telur yang produktif. Ayam ras merupakan jenis ras unggul dari hasil persilangan antara bangsa-bangsa ayam yang dikenal memiliki daya produktivitas yang tinggi terhadap produksi daging (karkas) dan telur.

Populasi ayam ras petelur di Sulawesi Utara mencapai 940.613 ekor dengan sentra produksi terdapat di beberapa daerah seperti Minahasa,
Bolaang Mongondow, Sangihe, Talaud, Kota Manado, dan Kota Bitung (Dinas Pertanian dan Peternakan Provinsi Sulawesi Utara, 2011). Hal ini menggambarkan pengembangan agribisnis ayam ras petelur di Sulawesi Utara telah berkembang dengan pesat dan sudah mencukupi/memenuhi kebutuhan masyarakat sekitar di daerah tersebut, sehingga memiliki potensi agribisnis untuk terus dikembangkan.

Perusahaan ayam ras petelur Dharma Gunawan adalah salah satu usaha peternakan ayam petelur di Kota Manado yang berlokasi di Kelurahan Paniki bawah Kecamatan Mapanget. Perusahaan ini beroperasi sejak tahun 1977 dan sampai saat ini terus mengembangkan usahanya. Untuk pengembangan usaha, maka perlu diketahui hubungan yang jelas antara biaya produksi, volume produksi dan berapa keuntungan perusahaan. Salah satu alat manajemen yang dapat menjelaskan hubungan antara biaya, volume produksi, dan keuntungan adalah analisis titik impas (Break Event Point). Untuk kebutuhan manajemen dalam usaha peternakan ayam petelur perlu dilakukan penelitian ini, untuk mengetahui titik impas dan keuntungan perusahaan.

\section{MATERI DAN METODE PENELITIAN}

Penelitian dilaksanakan di Kota Manado, pada perusahaan peternakan Ayam Ras Petelur Dharma Gunawan milik dari Bapak Gunawan yang terletak di Kelurahan Paniki Bawah Kecamatan Mapanget. Penelitian dilakukan sejak tanggal 4 April sampai tanggal 20 Mei 2012. 
Metode yang digunakan adalah metode studi kasus. Metode studi kasus (Case Study) merupakan suatu pendekatan dari penelitian yang bersifat kasus, sehingga hasil penelitian tidak dapat digeneralisasikan. Bahan-bahan yang dikumpulkan dan diteliti lazimnya melukiskan karakteristik yang terperinci dari suatu proses atau dari seluruh proses kehidupan suatu unit dengan berbagai hubungannya. Cara kerja metode kasus ini cukup mendalam sehingga dapat diketahui pula bagaimana cara mengatasi fenomena yang ada. Metode kasus umumnya menggunakan sampel secara kasus guna kepentingan tertentu dari tujuan penelitian.

\section{Model Analisis Data}

Model analisis yang digunakan dalam penelitian yaitu model analisis deskriptif dengan cara Verbal dan cara Matematis. Cara Verbal adalah cara yang menggunakan kata-kata untuk menerangkan sesuatu hal sedangkan cara Matematis dengan menggunakan analisis titik impas. Titik impas adalah suatu keadaan dalam hubungannya dengan produk, pada tingkat produksi tertentu perusahaan tidak akan memperoleh laba dan tidak menderita kerugian atau tingkat keuntungan sama dengan nol.

Analisis Titik Impas $(\mathrm{BEP}=$ Break Event Point) dihitung berdasarkan volume produksi (unit) dan penerimaan rupiah (Handoko, 1984; Riyanto, 1999; Ahmad, 2000).

$$
\mathrm{BEP}(\text { unit })=\frac{\mathrm{TFC}}{\mathrm{Hy}-\frac{T V C}{\mathrm{Y}}}
$$

$$
\operatorname{BEP}(\mathrm{Rp})=\frac{\mathrm{TFC}}{1-\frac{T V C}{\mathrm{~S}}}
$$

Keterangan :

$\mathrm{BEP}=$ Break Event Point

$\mathrm{TFC}=$ Total FixedCost

$\mathrm{TVC}=$ Total Variabel Cost

$\mathrm{Hy}=$ Harga jual produk/unit

$\mathrm{Y}=$ Kuantitas produksi (unit)

$\mathrm{S}=$ Hasil Penjualan/Total

Penerimaan

\section{Definisi Variabel Penelitian dan Pengukurannya.}

- Hargaadalahsatusatuannilaibarang dalambentuk rupiah (Rp).

- Penerimaanadalahjumlahnilai yang diterimasebagaihasilpenjualantelur , daging, pupuk, dikalikanharga (Rp/bulan).

- Biayatetapadalahbiaya yang jumlahnyaselalutetapuntukseluruhj umlahbarang yang dihasilkansampaitingkatproduksite rtentu. FC (Fixed cost) (Rp/bulan).

- Biayavariabeladalahbiaya yang besarnyaberubahubahsesuaidenganperubahan volume (jumlah) barang yang dihasilkanataudiproduksi. $\quad \mathrm{VC}$ (Variabel Cost) (Rp/bulan).

- Keuntunganadalahpenerimaan yang diperolehdikurangibiaya (Rp/bulan).

\section{HASIL DAN PEMBAHASAN}

\section{A.Pembibitan}

Managemenpembibitanayamra spetelurdilakukandengancaramembeli bibit $D O C$ di perusahaanpembibitan. Strain yang digunakanadalah Isa Brown dan MB 402. Biayapembelian $D O C$ sebesarRp 14.500,-/ekor. Stock DOC yang 
masukselama 1 tahunberkisarantara 3 - 4 kali stock atau 3-4 bulansekali. Masing-masing stock masukpadabulanJanuari, Juni, OktoberatauJanuari, April, Juli, danOktober.JumlahDOC yang masuksetiap 1 stock, berjumlah 2000 ekor - 4000 ekor.Dengan kata lainpemeliharaanayamraspetelur di perusahaaninimenggunakancara/siste mestafet.

Pada Tabel 1 akan dijelaskan jumlah rata-rata $D O C$ masuk dan pada Tabel 2 jumlah rata-rata ayam afkir, dari Januari 2010 - Januari 2012 atau 1 periode umur ayam yaitu selama 2 tahun.

Perlu diperhatikan 3 point penting dalam pemeliharaan ayam secara estafet.

1. Kegiatanseluruhpemeliharaanjuml ahayamhanyadihitungdaristock
pertamaDOCbulanJanuari 2010 sampaiayampada stock ituafkirpadaJanuari 2012. Berarti stock terakhir yang masukpada 1 periodeterakhirterjadidibulanoktob er 2011.Jumlahayam rata-rata 17000 ekor.

2. KegiatanpadaJanuari 2012, stock DOCdihitungkarenaterjadijugakegi atanayamafkir, berartihanyadilihatbiayapengeluara npembelianDOCdanbiayapemasuk andaripenjualanayamafkir.

Kegiatan ayam afkir berjumlah lebih sedikit dari kegiatan ayam $D O C$, karena terjadi mortalitas $15 \%-20 \%$ setiap stock dan lebih banyak dari pemeliharaan ayam yang masih aktif, karena kegiatan itu dihitung dari kegiatan-kegiatan 1 periode umur ayam atau 2 tahun sebelumnya.

Tabel 1. Jumlah Rata-rata DOC pada Januari 2010 - Januari 2012

\begin{tabular}{|c|c|c|c|}
\hline No & Bulan & Tahun & Jumlah ekor \\
\hline 1 & Januari & 2010 & 4000 \\
\hline 2 & Juni & 2010 & 2000 \\
\hline 3 & Oktober & 2010 & 2000 \\
\hline 4 & Januari & 2011 & 3000 \\
\hline 5 & April & 2011 & 2000 \\
\hline 6 & Juli & 2011 & 2000 \\
\hline 7 & Oktober & 2011 & 2000 \\
\hline 8 & Januari & 2012 & 4000 \\
\hline \multicolumn{3}{|c|}{ Total } & 21000 \\
\hline
\end{tabular}

Tabel 2. Jumlah Rata-rata Ayam Afkir pada Januari 2010 - Januari 2012

\begin{tabular}{llcc}
\hline No & Bulan & Tahun & Jumlah ekor \\
\hline 1 & Januari & 2010 & 3200 \\
2 & Juni & 2010 & 1700 \\
3 & Oktober & 2010 & 1700 \\
4 & Januari & 2011 & 2400 \\
5 & April & 2011 & 1700 \\
6 & Juli & 2011 & 1700 \\
7 & Oktober & 2011 & 1700 \\
8 & Januari & 2012 & 3200 \\
\hline & & & 17300 \\
\hline
\end{tabular}




\section{B. Kandang dan Perlengkapannya}

Bangunan kandang berjumlah 15 unit, yang terdiri dari 1 unit kandang $D O C, 1$ unit kandang grower, dan 12 unit kandang layer dan 1 bangunan gudang tempat penggilingan jagung, pencampuran dan penyimpanan pakan. Pajak dari perizinan pembangunan perusahaan peternakan ini adalah Rp 700.000,/bulan

Kandang DOC bagian luar mempunyai ukuran lebar 5 meter, panjang 7,5 meter dan tinggi 3 meter, berbahan semen, pasir, kerikil, batu bata, ram bangunan, kayu dan seng, Diameter di dalam kandang berukuran lebar 2 meter, panjang 2,4 meter dan tinggi $62 \mathrm{~cm}$ dengan bahan kayu, alas dari kandang ini menggunakan pasir dan kapur secukupnya, sekam padi, serutan kayu dan serbuk gergaji atau disebut dengan lantai alas litter. Amazonise (2012), melaporkan bahwa $D O C$ ini harus dipelihara dalam kandang koloni berlantai litter (sekam padi) dan harus diberi pemanas. Ada banyak alat pemanas kandang ayam, antara lain berupa lampu listrik, lampu minyak, kompor minyak dan kompor berbahan bakar briket batubara. Alas lantai/litter harus dalam keadaan kering, maka tidak ada atap yang bocor dan air hujan tidak ada yang masuk walau angin kencang. Tebal litter setinggi $10 \mathrm{~cm}$, bahan litter dipakai campuran dari kulit padi/sekam dengan sedikit kapur dan pasir secukupnya, atau hasil serutan kayu dengan panjang antara 3-5 cm untuk pengganti kulit padi/sekam (Cahyono, 1995; Omkicau, 2010).Alas kandang (litter) beserta kotoran (feses) dibersihkan setiap bulan sekali (Samadi, 2010).

Kandang grower bagian luar berukuran lebar 5 meter, panjang 7,5 meter dan tinggi 3 meter berbahan semen, pasir, kerikil, kayu dan seng. Kandang dalam jenis baterai terbuat dari ram besi, berbentuk sangkar atau kotak, memiliki panjang 6 meter, sebanyak 12 unit dan 3 tingkat.

Kandang layer bagian luar mempunyai ukuran lebar 5,5 meter, panjang 30 meter dan tinggi 3 meter berbahan semen, pasir, kerikil, kayu dan seng. Kandang dalam tipe baterai memakai bahan ram besi, berbentuk sangkar atau kotak, perunitnya memiliki panjang $90 \mathrm{~cm}$ yang terdiri dari 4 kotak dan 1 kotak yang dapat menampung $1-2$ ekor ayam, dalam 1 kandang terdiri dari 165 unit, disusun berderet memanjang dan memiliki 2 tingkat.

Untuk beternak ayam ras petelur digunakan kandang tipe baterai (kandang individual $=$ kandang cage $)$ (Cahyono, 1994; Samadi,2010; Amazonise, 2012). Kandang baterai (sangkar) berbentuk empat persegi panjang dan disusun berderet-deret, serta bertingkat (Samadi, 2010). Kandang tipe baterai yaitu merupakan kandang yang berbentuk sangkar empat persegi panjang yang disusun secara berderet memanjang dan bertingkat tiga atau empat. Kandang baterai juga dikenal sebagai kandang individual karena setiap sangkar hanya untuk satu ekor ayam. Sistem kandang baterai untuk beternak ayam petelur dipandang lebih menguntungkan karena dapat meningkatkan produktivitas ayam menghasilkan telur (Cahyono, 1994; Samadi, 2010). Kandang dibuat dari bahan-bahan 
yang berkualitas sehingga kuat dan tahan lama penggunaannya. Misalnya, menggunakan bambu, kayu, kawat ram, dan bahan bangunan lainnya seperti semen, pasir dan batu bata. Untuk sangkar berukuran panjang 45 $\mathrm{cm}$, lebar $25 \mathrm{~cm}$, dan tinggi $40 \mathrm{~cm}$ (berisi 1 ekor ayam), atau panjang 40 $\mathrm{cm}$, lebar $60 \mathrm{~cm}$, tinggi $40 \mathrm{~cm}$ (berisi 3 ekor ayam), atau panjang $40 \mathrm{~cm}$, lebar $45 \mathrm{~cm}$, tinggi $40 \mathrm{~cm}$ (berisi 2 ekor ayam) (Cahyono, 1994 ; Samadi, 2010).

Umumnya kandang baterai untuk ayam petelur terbuat dari bambu dan logam. Kandang bambu lebih cocok untuk usaha peternakan ayam petelur skala rumah tangga, sementara kandang dari logam cocok untuk usaha peternakan skala besar. Kandang bambu investasinya sangat rendah, namun penyusutannya juga cepat. Sementara kandang logam biaya investasinya tinggi namun penyusutannya juga lama. Hingga sebenarnya, kandang logam jatuhnya lebih murah dibanding kandang dari bambu (Amazonise, 2012).

Gudang penggilingan, pencampuran dan penyimpanan, memiliki lebar 10 meter, panjang 20 meter dan tinggi 3 meter berbahan semen, pasir kerikil, batu bata, ram nyamuk, kayu dan seng. Tersedia mesin penggilngan jagung 1 unit dan mesin mixer ukuran raksasa 1 unit. Mesin-mesin itu digunakan untuk menggiling jagung dan mencampur makanan ternak.

Biaya pembuatan kandang dan gudang, dapat diamati pada Tabel 3.

Pada Tabel tersebut dapat dilihat bahwa, biaya pembuatan seluruh kandang dan gudang pakan adalah sebesar Rp 767.244.000,-. Untuk penyusutannya setiap bangunan dibagi menjadi 3, kandang luar $15 \% /$ tahun dengan biaya pembuatan $\mathrm{Rp}$ 514.470.000,-, kandang dalam $25 \% /$ tahun dengan biaya $\mathrm{Rp}$ 102.774.000,- dan gudang pakan 15 $\% /$ tahun biaya pembuatan $\mathrm{Rp}$ 150.000.000,-.

\section{Penerangankandang:}

Di dalam kandang, sangat perlu untuk menggunakan fasilitas seperti lampu, kabel, sakelar. Banyaknya unit lampu-lampu tersebut adalah 32 unit untuk lampu pijar dengan harga $\mathrm{Rp}$ 10.000,-/unit dan lampu neon kuning 156 unit harga 1 unit dari neon ini $\mathrm{Rp}$ 30.000,-/unit. Lampu neon ini telah dikalikan dengan banyaknya jumlah kandang grower dan layer, karna setiap 1 kandang memakai 12 unit lampu.

Pembelian kabel dan sakelar, dipakai kurang lebih $400 \mathrm{~m}$ kabel dengan harga $\mathrm{Rp} 750,-/ \mathrm{m}$ dan sakelar 15 unit dengan harga $\mathrm{Rp} 8.000 /$ unit. Berarti untuk seluruh biaya pembelian lampu, kabel, sakelar sebesar Rp 5.420.000,-. Seperti yang disebutkan tadi bola lampu yang putus dalam 1 bulan rata-rata $2-3$ bola, 1 lampu pijar dan 2 lampu neon, harga dari lampu yang rusak Rp 70.000,-/bln, berarti sama besar dengan biaya untuk menggantinya selama 1 bulan, bila ditambahkan dengan kabel dan sakelar yang rusak, kira-kira dalam 1 bulan biaya untuk mengganti seluruhnya lampu, kabel dan sakelar Rp 100.000,, dikalikan 2 tahun/24 bln, biaya pembeliannya sebesar Rp 2.400.000,-Biaya listrik selama 1bulan Rp 1.100.000,-. Total biaya peralatan kandang adalah Rp.84.475.000. 
(Delapan puluh empat juta empat ratus tujuh puluh lima ribu rupiah)

\section{Pakan dan Air Minum}

Perusahaan ini menggunakan 3 (tiga) jenis pakan dengan harga yang berbeda yaitu Butiran/makanan jadi (pakan DOC) Rp 5.750,-/kg, Benefit K5 (pakan grower) Rp 3.450,-/kg dan Konsentrat, jagung, tepung ikan, konga, greed, konfit dll (pakan finisher/layer) Rp 3.700,-/kg. Biaya pakan selama 2 tahun sebesar $\mathrm{Rp}$ 5.034.840.700,--

Menurut Rasyaf (2008), nilai konversi pakan yang baik adalah kurang 1 dimana pada nilai tersebut pakan digunakan sebaik-baiknya dan konversi lebih dari satu artinya konversi buruk, ayam yang sudah tua atau baru mulai bertelur atau adanya pencurian telur. Dijelaskan lebih lanjut oleh Rasyaf (2008) menyatakan bahwa tingkat konversi pakan yang berbedabeda tergantung kadar protein dan energi metabolisme pakan, suhu lingkungan, umur ayam, kondisi kesehatan dan komposisi pakan. Apabila nilai konversi pakan semakin kecil maka konversi pakan baik, berarti ayam petelur dapat menggunakan pakan dengan baik dan dapat menghasilkan produksi telur dengan baik.

Air minum pada ternak di perusahaan ini diberikan secara tidak terbatas (adlibitium), yang diambil dari sumur bor menggunakan mesin pompa air 250 watt, dengan kata lain biaya air bebas atau gratis. Sedangkan biaya pembelian mesin pompa air yang digunakan sebanyak 2 unit dengan harga $\mathrm{Rp} \mathrm{1.500.000,-/unit,}$ berarti Rp 3.000.000,- untuk 2 unitnya. Pemberian air minum untuk ternak diberikan secara tidak dibatasi (adlibitium) yaitu wadah air minum harus selalu terisi air. Oleh karena itu, jika wadah air minum tampak airnya tinggal sedikit maka harus diisi lagi hingga penuh. Kebutuhan air minum ayam dewasa sekitar $20 \quad 1 / 100$ ekor/hari. Air minum yang diberikan harus bersih dan sejuk, baik yang berasal dari sumur artetis, mata air, maupun dari perusahaan air minum (PAM) (Samadi, 2010).

\section{Tenaga Kerja}

Peternakan ini memiliki 13 tenaga kerja, dengan 10 buruh kandang, 2 sopir dan 1 pembantu. Kegiatan yang dilakukan adalah mencampur pakan, memberi pakan, minum, memberi vaksin dan obatobatan, membersihkan kandang, memungut telur, membersihkan telur, memilih telur, menjual telur, mengantar telur ke pasar/ supermarket dan lain-lain.

\section{E. Pencegahan Penyakit, Pengobatan dan Sanitasi Kandang}

Pemberian obat-obatan dan vitamin ini diberikan sesuai kebutuhan ternak. Obat yang dipakai untuk ternak ayam ini adalah antibiotik dan koleridin, sedangkan untuk vitamin diberikan jenis multivitamin, vitacid, super power, strong eight. Apabila pengobatan tidak juga berhasil, maka ayam akan mati dan harus dibuang/dibakar. 


\section{F. Transportasi}

Untuk memasarkan telur ayam diperlukan alat transportasi dan yang digunakan adalah kendaraan milik perusahaan.

\section{G. Pemasaran}

Produk telur ayam ini dikomersilkan atau dijual ke pasar yaitu pasar Paal 2, warung-warung kecil, dan supermarket yaitu Jumbo, Fiestaria dan Gelael (Mega Mall). Harga menurut jenis ukuran.

- $\quad$ Telurkecil :Rp 700,- s/d Rp 860,rata-rata $=\mathrm{Rp} 780$,-/butir.

- Telursedang :Rp 900,- s/d Rp 970,- rata-rata $=\operatorname{Rp} 935,-/$ butir.

- Telurbesar :Rp 1.050 s/d Rp 1.150 rata-rata $=\mathrm{Rp} 1.100,-$ /butir.

\section{Analisis BEP (Perhitungan dari Januari 2010 - Januari 2012}

\section{Total biaya Produksi}

Total biaya tetap + Total biaya variable $=R p 413.793 .000+R p$ 6.298.040.700 = Rp 6.711.833.700,-

\section{Pendapatan}

Total penerimaan - Total biaya produksi $=\mathrm{Rp}$ 9.005.880.760 $-\mathrm{Rp}$ 6.711.833.700 = Rp 2.294.047.060,-

$$
\begin{aligned}
& \operatorname{BEP}(\text { unit })=\frac{\mathrm{TFC}}{\mathrm{Hy}-\frac{T V C}{\mathrm{Y}}} \\
& \operatorname{BEP}(\mathbf{R p})=\frac{\mathrm{TFC}}{1-\frac{T V C}{\mathrm{~S}}}
\end{aligned}
$$

Keterangan :

$\mathrm{BEP}=$ Break Event Point

TFC $=$ Total FixedCost

$\mathrm{TVC}=$ Total Variabel Cost

$$
\begin{aligned}
\mathrm{Hy}= & \text { Harga jual produk/unit } \\
\mathrm{Y}= & \text { Kuantitas produksi (unit) } \\
\mathrm{S}= & \text { Hasil Penjualan/Total } \\
& \text { Penerimaan }
\end{aligned}
$$

$\mathbf{B E P}($ unit $)=\frac{\mathrm{TFC}}{\mathrm{Hy}-\frac{T V C}{\mathrm{Y}}}$

Telur rata-rata $=$

$$
\begin{aligned}
& \frac{413.793 .000}{938,33-\frac{6.298 .040 .700}{8.772 .000}}=\frac{413.793 .000}{938,33-717,97} \\
& =\frac{413.793 .000}{220,36}=1.877 .804,51
\end{aligned}
$$

$$
\begin{array}{r}
\text { BEP }(\mathbf{R p})=\frac{\text { TFC }}{1-\frac{T V C}{\mathrm{~S}}} \\
=\frac{413.793 .000}{1-\frac{6.298 .040 .700}{8.231 .030 .760}} \\
=\frac{413.793 .000}{1-0,77} \\
=\frac{413.793 .000}{0,23} \\
=1.799 .100 .000
\end{array}
$$

Pada usaha ternak ayam ras petelur ini mencapai Titik Impas pada angka 1.877.804,51 untuk unitnya dan untuk Titik Impas rupiahnya mencapai $\mathrm{Rp}$ 1.799.100.000,- dari hasil penjualan telur rata-rata. Artinya pada unit 1.877.804,51 atau penerimaan sebesar Rp 1.799.100.000,- usaha ini mencapai Break Event Point atau perusahaan belum mendapat keuntungan atau keuntungan sama dengan nol.

\section{KESIMPULAN}

\section{Kesimpulan}

- Dalampengalokasianbiayapadaper usahaanpeternakanayamraspeteluri nimenyangkutbiayatetap total $\mathrm{Rp}$ 
413.793.000,-, biayavariabel total Rp 6.298.040.700,- danpenerimaan total Rp 9.019.195.160,-

- Keuntungan usahaternakayamraspetelurinidihit ungdariJanuari 2010 - Januari 2012 (1 kali periodeproduksi) yaituRp 2.307.361.460,-

- TitikImpastercapaipada unit1.877.804,51

danpadapenerimaansebesarRp 1.799.100.000,-

darihasilpenjualantelur rata-rata. Usaha

iniprospektifdanmenguntungkan.

\section{Saran}

- Perludijagadandipertahankankebe rsihankandang agar ayamtidakgampangterkenapenyak itdanmengurangiangkamortalitasa yam, sertamenekanbiayaobatobatandan vitamin agar usahainilebihmenguntungkan.

- Sebaiknyatelur yang tidak laku atau sisa telur yang tidak terjual,dibuat menjadi makanan awet dan tahan lama berupa kue, telur asin dan lain sebagainya, untuk dijual di toko-toko, supermarket, pasar, atau rumah makan, bukan hanya untuk dikonsumsi sendiri, agar menambah pendapatan.

\section{DAFTAR PUSTAKA}

Ahmad, K. 2000. Akuntansi Manajemen: Dasar-dasar konsep biaya dan pengambilan keputusan, edisi pertama, cetakan ketiga, PT. Raja Grafindo Persada, Jakarta.
Amazonise. 2012. Tips Cara Ternak dan Budidaya Ayam Petelur.http://amazonise.wordp ress.com/2012/02/20/tips-carateranak-dan budidaya-ayampetelurDiakses tanggal 18 Oktober 2012.

Cahyono, B. 1994. Beternak Ayam Ras Petelur dalam Kandang Baterai (Solo : CV. Aneka).Dinas Pertanian dan Peternakan Provinsi Sulawesi Utara. 2011.

Handoko, TH. 1984. Edisi ke 1, Dasar-dasar Manajemen Produksi dan Operasi, Yogyakarta; BPFE_Yogyakarta.

Omkicau. 2010. Budidaya Ayam Ras Petelur.

http://omkicau.com/hobilain/berbagai-peluang-usahabidang-peternakanperkebunan/budidaya-ayamras-petelurDiakses tanggal 18 Oktober 2012.

Rasyaf,M. 2008. Panduan Beternak Ayam Petelur, Penebar Swadaya,

Depok.http://nuansatelur.com/2 013/04/09/jenis-ayam-raspetelur/Diakses tanggal 22 Mei 2013.

Riyanto, B. 1999.Dasar-Dasar Pembelanjaan Perusahaan, Edisi Lima, BPFE; Yogyakarta.

Samadi, B. 2010. Sukses Beternak Ayam Ras, Pedaging dan Petelur. Cet I. Diterbitkan oleh Pustaka Mina, kelompok Penerbit Papas, anggota Ikapi

Jakarta. 